\title{
Research on the Construction of Vibrant Classroom
}

\author{
Shunjun Sheng \\ Shanghai Normal University Tianhua College \\ Shanghai 201815, China
}

\begin{abstract}
The effectiveness of classroom teaching often depends on the overall atmosphere of the classroom as well as the emotional attitude between teachers and students. However, nowadays, many college classrooms are lifeless and stagnant. Is it the teachers' responsibility or students' problem? This paper tries to make an in-depth analysis from the aspects of the roles and qualities that teachers should have and those students should have in teaching, on the basis of which classroom teaching mode with "three dynamics" has been provided in order to contribute to the current reform on college classroom.
\end{abstract}

Keywords—vibrant classroom, useful, interesting, effective

\section{INTRODUCTION}

Classroom teaching is a way of living and acting. Classroom environment or classroom life atmosphere becomes a supportive or frustrating condition for students in classroom life. ${ }^{1}$ College classroom teaching is a place for knowledge sharing and also an important platform for teachers to impart knowledge and for students to learn knowledge and develop attitude and ability. However, according to my teaching experience in universities, I feel there are still many problems in classroom teaching. For example, boring teaching contents, students' inattention in class, depressed classroom atmosphere, and random teaching arrangement, etc., all these phenomena hinder the realization of classroom teaching value. It is not only an important task for the teaching management of colleges but also the responsibility of each teacher to attach great importance to the above classroom phenomenon and think about the reasons for this phenomenon.

\section{The CurRent Situation of College Classroom}

College classroom should be a place where knowledge sparks collide. However, looking back on today's college classroom, we have to reflect that is it the decline of teachers' professional quality or are students less interested in learning? If so, how can we solve it?

Many teachers should be impressed with students sleeping in college classes, but why do these students choose to sleep in class? According to the author's personal survey, many students who are sleeping in classroom say they would sleep in relevant classrooms, not in all classrooms, which sends a message to us: what kind of classes do they sleep in?

It is very common to play mobile phone in classroom. Why they play it in classroom? Would they play it in all classrooms? of course not. It sends us such a message: in what kind of classes do they play with their mobile phone?

There are other phenomena such as late for class, class chat among classmates, going to the toilet in the middle of classes, which further make us reflect: what happened to these students and why they cannot be concentrated on classroom study?

All these are very common to see in college classrooms. However, when the above situation occurs, many college teachers are accustomed to the situation, or even turn a blind eye on them. And many teachers choose to do nothing. If these situations have been continuing, then what on earth can higher education do for college students? What are college teachers' responsibilities? And how can we make students not sleep, not play with their phones and be attentive in classroom? These are the intention for writing this paper.

When talking about the state of students in class, students say that they will not be in a good state in some classes, will be in good state in some classes, then what kind of class will make students be in an active state? Is there a logic that rejuvenates our college classrooms, that no longer makes students feel like that "every second is an hour long" in class and that no longer makes our college teachers feel like that they are "reading the book" to complete a routine task?

Then what kind of classroom is vibrant classroom? When speaking of "vibrancy"[1], one may think of noisy classroom scenes. In fact, a noisy classroom may not necessarily be a vigorous one. So what is a vibrant classroom?

The author holds that college education is the one that guides value orientation, which contains the value selection and goal setting. And the first and the most important step is to set up teaching objectives in college education. Teachers must clearly understand what should be taught in the class, which is the most basic requirement for the implementation of teaching. Only when there is a clear teaching goal can we design the teaching process according to the teaching objectives, implement these objectives in the teaching process and use the appropriate evaluation means to test the learning effect of students.

So in the process of constructing vibrant classroom, what roles do teachers and students assume respectively? In view of this, the author reflects the aspect of teachers and students to give some personal suggestions.

\footnotetext{
${ }^{1}$ John Dewey. Democracy and Education[M]. Wang Chengxu translate. Beijing: People Education Press, 2001
} 


\section{The Teaching Role Teachers Should Assume AND THE QUALITY THEY SHOULD HAVE}

The author believes that teachers play an absolute guiding role in classroom. Their emphasis on the classroom will directly affect the state of students. However, under the influence of Dewey's instrumentalism ${ }^{2}$, traditional teaching concepts and other relevant factors, teachers in institutions of high learning seldom pay special attention to designing teaching plans based on the comprehensive development of students. In the process of teaching, teachers put cognitive goals in the first place and pay little attention to or even neglect non-cognitive goals [2]. In this kind of classroom teaching which emphasizes cognition over non-cognition and replaces everything with the direct impartment of knowledge, the goal of classroom teaching is to let students to master knowledge in textbooks. When teachers only pay attention to the knowledge what students have recited and ignore the improvement of their own ability, then it is impossible to pay attention to their learning motivation, interest and attitude.

Based on the above reasons, the author believes that it should start with the transformation of teachers' way of thinking and let each teacher know their mission. Before each course, a teaching outline of the course can be prepared and delivered to learners of the course at the beginning of each semester.

Useful means that students can apply what they have learned. What teachers teach should be valuable to students. And students should learn knowledge as much as possible and use them in their life. The usefulness of teaching contents not only means that it is useful to students for a short period of time, so that students can learn practical knowledge, develop ability and improve work efficiency, but also means that the contents taught has the power to sustain students' lifelong development, so that students can improve their comprehensive ability and form correct values. It requires teachers to be able to fully connect the theory with the reality in teaching and explain actual problems with theories, which can reflect the depth in explaining actual problems with knowledge from textbooks. Take the accounting analysis in the course of accounting management as an example, when analyzing the profitability of a company; it must combine it with those of current listed companies to make an explanation. By doing so, students can have an understanding on the framework of analysis on the profitability of listed companies. Additionally, it can demand them to make an in-depth analysis on a listed company after class and form an analysis report to submit, thus rooting such an ability into their mind.

Interesting means that classroom teaching makes students have fun. Interest is the best teacher. If the teaching contents in class are boring, then students will find it boring too. And teachers will mechanically instill knowledge into students for the completion of teaching tasks in an endless cycle. So, it requires teachers to take the actual situation of students

\footnotetext{
${ }^{2}$ Broadly speaking, instrumentalism is another name of pragmatism of Dewey. Narrowly speaking, it refers to theories on cognition and truth. The basic opinion is that ideology, conception and theory are tool for people's behavior. The criterion of their truth lies in whether they can guide people to achieve success.
}

background into consideration, improve their teaching plans, use informatization technology and teaching resources in a reasonable way, adopt various forms of classroom teaching and select appropriate teaching methods, enhance their language charm in class so as to let the classroom full of vitality and make students be "active" to feel learning fun, thus transforming from "making them learn" into "they are eager to learn". The funny thing here doesn't mean just telling jokes in class, making students laugh, which will be nothing except for funny after recalling it. What is interesting here is that teachers can think about professional teaching and explain it vividly by analogy, so that theoretical knowledge can be easily understood by students. It requires teachers to accumulate more knowledge and experience in their lives and be more concerned about current affairs to form a system, thus they can make the classroom interesting and impart knowledge in a funny way. The requirement for interesting is not only the interesting language, but also the combination of textbook knowledge with practice in daily teaching, which is the wisdom reflected in practical problems solved by the book knowledge. Take the basic course of preliminary accounting in financial management as an example, when we talk about the eight quality requirements ${ }^{3}$ of accounting information, we can use the simplest example of making friends in life to make a comparison. The company is a legal person and we are an individual, so when we go to understand a company, what do you think is the most important? Many students say they don't know. Then when we make friends in our life, what do you think is the most important thing? The students would say that character is the most important thing. Then we can guide students to think what kind of feelings can a person' character bring? Many students will say reliable. By doing so, we can impart theoretical knowledge to students step by step and let them to learn in a relaxed and interesting atmosphere, thus achieving twice the result with half the effort.

Effectiveness means to get students to learn something. Teachers' input in classroom teaching matches with students' acquisition in class, thus realizing teaching objectives, which is called effectiveness. Additionally, it also refers to far-fetching influence on students' study. Teachers should not only focus on the matching of their input and students' acquisition, but also pursue teaching effect and pay attention to far-reaching effect, so that every student can learn something with continuing learning desire. It requires teachers to carefully prepare each class with established objectives when conducting teaching in classroom, thus achieving the expected effect within short period of classroom teaching.

\section{The Roles AND QuALITIES OF STUDENTS IN TEACHING}

In view of the objectives in "three aspects" in classroom teaching, it requires students to be able to be attentive in "three aspects": be attentive in eyes, hands and mind.

Be attentive in eyes means that students can concentrate on class. When teachers make the classroom interesting, the author thinks that students will be naturally attracted by the

\footnotetext{
${ }^{3}$ Eight quality requirements refer to liability, relevance, intelligibility, and comparability, emphasis on contents over form, importance, timeliness and pertinence.
} 
teaching, thus paying attention to the class contents and being attentive in class. Only when students concentrate on classroom teaching, what teachers impart can be naturally learned by students. Be attentive in eyes we mention here is just a beginning for teachers to attract the attention of students. Be attentive in eyes not only requires teachers to make classroom teaching interesting, but also requires students to read and think after class. By doing so, the interesting classroom teaching can integrate with students' attention in class, thus truly achieving deep interaction in class [5].

Be attentive in hands refers to focusing on note-taking in class. As the old saying goes: "note-taking is better than a good memory", it is very useful in any courses study. Only when students feel the course is useful can they take notes in class. The premise that makes students feel it useful is also to demand them to be able to preview sufficiently before classes and combine with teachers' teaching in class. By doing so, they can really take notes purposely with which they are unfamiliar, thus harmonizing usefulness with hands and further achieving deep interaction in class.

Be attentive in mind refers to focus on classroom wholeheartedly. When students are attentive in eyes and hands due to teachers' interesting and useful teaching, then their attention in study can match with the usefulness of teaching contents, which further requires students to preview and review teaching contents before class, in class and after class, thus being focused on study wholeheartedly. By doing so, the whole classroom teaching can be integrated into one with teaching and learning promoted each other, thus ultimately realizing two-way cycle of "vibrancy-interaction and activeness" in class we desire[6].

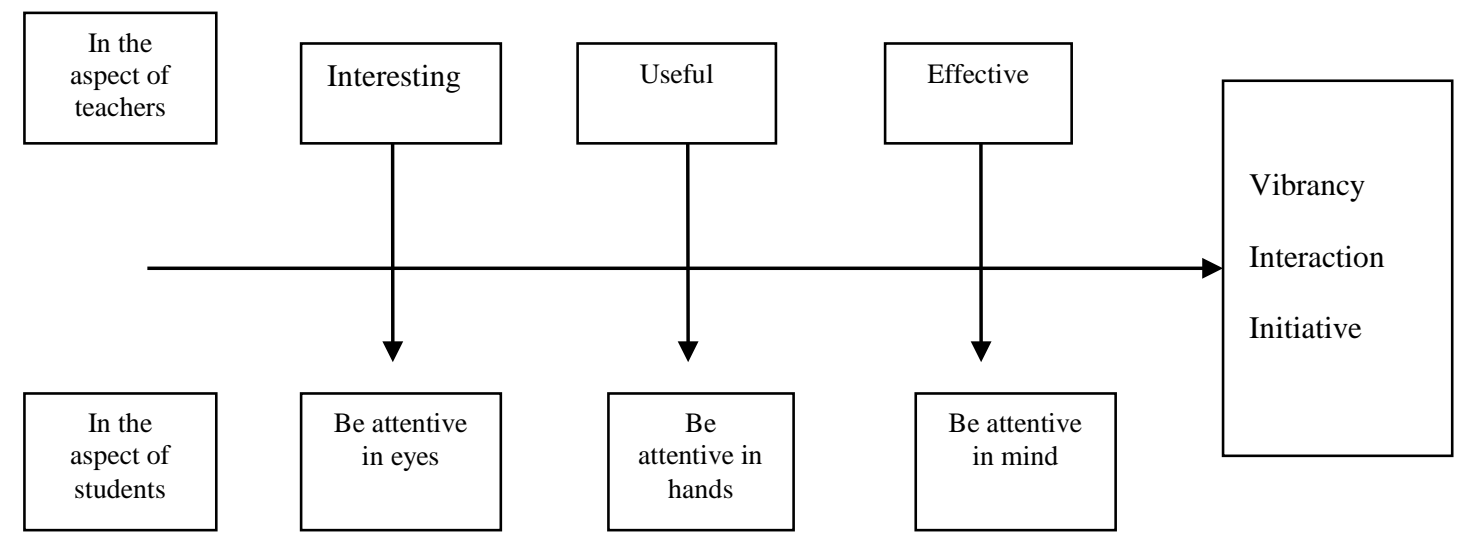

Fig. 1. Diagram of vibrant classroom

\section{The EnLightenMent OF ClAssRoOm TEACHING}

Through the above interpretation on "three aspects" of teachers and students, we roughly know that teachers and students should work together to make classroom teaching "be vibrant in three aspects", that is, "vibrancy, interaction and initiative", thus a vibrant classroom can be built.

Vibrancy means that classroom teaching is very interesting which makes students be willing to listen to and attracts their attention. By doing so, the classroom teaching can become the real place for imparting knowledge. Interaction is useful in teachers' teaching, which makes students be willing to listen to, take note and think, thus forming sound interactive classroom and teaching atmosphere. With sound teaching atmosphere, sound study atmosphere can be realized. When sound study atmosphere is formed, students' activeness in study can be further promoted, thus realizing sound study cycle of "vibrancy, interaction and initiative".

In addition, the vibrancy of teaching mode in these three aspects should be carried out in accordance with specific situations of different colleges and students. And heuristic education should be emphasized to make the whole course be vibrant.

\section{REFERENCES}

[1] Liu Xiaohong. Analysis on the Crisis and its Reasons of Classroom Teaching in Institutions of High Learning[J]. The Guide of Science \& Education, 2015 (9). pp.21-22 (In Chinese)

[2] Pei Wei. On Creating Effective Situation and Building Vibrant Classroom Teaching[J]. The Science Education Article Collects, 2014 (3). pp.184-185 (In Chinese)

[3] Yao Lei. Analysis on Choice of Effective Interactive Mode in Classroom in Institutions of High Learning[J]. Education and Teaching Forum, 2016, March, (12): pp.205-206 (In Chinese)

[4] Lin Daxian. On Self-Study Based on Subject Ability--An Attempt to Build Teaching Mode of "Ability-Oriented Effective Classroom Teaching[J]. Preliminary Education forum, 2015(2). pp.53-54 (In Chinese)

[5] Li Cunsheng. Cultural Shared Community in the Classroom: Path for Effective Classroom Teaching Practice $[\mathrm{J}]$. Education Exploration, 2014(9). pp.22-24 (In Chinese)

[6] Wang Ailing. On the Construction of Effective Evaluation System[J].Theory and Practice of Education. 2014. Vol. 34 (34). pp.5255 (In Chinese) 